NBER WORKING PAPER SERIES

\title{
LEVELS AND TRENDS IN UNITED STATES INCOME AND ITS DISTRIBUTION A CROSSWALK FROM MARKET INCOME TOWARDS A COMPREHENSIVE HAIG-SIMONS INCOME APPROACH
}

\author{
Philip Armour \\ Richard V. Burkhauser \\ Jeff Larrimore \\ Working Paper 19110 \\ http://www.nber.org/papers/w19110 \\ NATIONAL BUREAU OF ECONOMIC RESEARCH \\ 1050 Massachusetts Avenue \\ Cambridge, MA 02138 \\ June 2013
}

We thank Scott Winship and Tim Smeeding as well as the participants of the Perspectives on Inequality and Mobility session at the 2013 AEA/ASSA conference-especially James Ziliak-for their comments on earlier drafts of this paper. An abbreviated version of an earlier draft of this paper presented at the AEA/ASSA conference appeared in the 2013 AER papers and proceedings issue. The authors have no material financial interests that relate to the findings described in this paper and received no outside financial support for the research. Burkhauser over the past 12 months has received funding in excess of \$5,000 from the National Institute on Disability and Rehabilitation Research and the American Enterprise Institute. In addition he received funding not in excess of \$5,000 from: The Brookings Institution, Employment Policies Institute, Pew Charitable Trusts, and the Smith Group. All opinions are those of the authors and should not be attributed to the Joint Committee on Taxation or any Member of Congress. The views expressed herein are those of the authors and do not necessarily reflect the views of the National Bureau of Economic Research.

NBER working papers are circulated for discussion and comment purposes. They have not been peerreviewed or been subject to the review by the NBER Board of Directors that accompanies official NBER publications.

(C) 2013 by Philip Armour, Richard V. Burkhauser, and Jeff Larrimore. All rights reserved. Short sections of text, not to exceed two paragraphs, may be quoted without explicit permission provided that full credit, including $\left({ }^{\circ}\right.$ notice, is given to the source. 
Levels and Trends in United States Income and Its Distribution]

A Crosswalk from Market Income Towards a Comprehensive Haig-Simons Income Approach Philip Armour, Richard V. Burkhauser, and Jeff Larrimore

NBER Working Paper No. 19110

June 2013

JEL No. C81,D31,H24,J3

\begin{abstract}
$\underline{\text { ABSTRACT }}$
Recent research on United States levels and trends in income inequality vary substantially in how they measure income. Piketty and Saez (2003) examine market income of tax units based on IRS tax return data, DeNavas-Walt, Proctor, and Smith (2012) and most CPS-based research uses pre-tax, post-transfer cash income of households, while the CBO (2012) uses both data sets and focuses on household size-adjusted comprehensive income of persons, including taxable realized capital gains. This paper provides a crosswalk of income growth across these common income measures using a unified data set. It then uses a more consistent Haig-Simons income definition approach to comprehensive income by incorporating yearly-accrued capital gains to measure yearly changes in wealth rather than focusing solely on the realized taxable capital gains that appear in IRS tax return data. Doing so dramatically reduces the observed growth in income inequality across the distribution, but most especially the rise in top-end income since 1989.
\end{abstract}

\author{
Philip Armour \\ Cornell University \\ 404 Uris Hall \\ Ithaca, NY 14853 \\ poa8@cornell.edu \\ Richard V. Burkhauser \\ Cornell University \\ Department of Policy Analysis \& Management \\ 259 MVR Hall \\ Ithaca, NY 14853-4401 \\ and University of Melbourne \\ and also NBER \\ rvb1@cornell.edu
}

Jeff Larrimore

Joint Committee on Taxation

1625 Longworth House Office Building

Washington, D.C. 20515

jeff.larrimore@mail.house.gov 
Much of the debate over the distributional fairness of fiscal policies is discussed in the context of the current distribution of income in the United States and how it has changed over time. Given the importance of income statistics in such debates, there is a surprising lack of consensus in the economics literature over what should be counted as income in distributional analyses. Most economists agree that cash market income, such as labor earnings, interest, and dividends should be included. But should income be measured on a pre-tax or post-tax basis? Should cash transfers such as Social Security, unemployment, and disability payments be included? What about in-kind benefits such as employer-provided health insurance, Medicare, Medicaid, food stamps (SNAP), or school lunches? Further, should capital gains be included and, if so, should it be on a yearly accrual basis or at realization?

We will show that the answers to these questions profoundly impact observed levels and trends in "income" and its distribution. Too often, the choice of income definition has been based primarily on data availability—with research based on IRS tax records concentrating on pre-tax, pre-transfer cash market income of tax units, and research based on March Current Population Survey (CPS) data focusing on pre-tax, post-transfer cash income of households excluding capital gains.

While data availability concerns will always be a factor in measuring income, from a theoretical basis, the Haig-Simons income definition is an attractive standard for calculating annual income. Under this definition, an individual's yearly income is defined as that person's consumption plus his or her change in net wealth in that year. (See Auerbach, 1989 and Barthold, 1993 for discussion of the Haig-Simons approach in the context of tax policy.) Such a definition nicely links yearly consumption, which is most fundamentally related to economic well-being but rarely available, with a measure of income that can largely be measured with available data. 
Burkhauser, Larrimore, and Simon (2012) and Congressional Budget Office (CBO) (2012) provide the most recent efforts to broaden an income definition based solely on IRS tax records toward a more comprehensive Haig-Simons income measure using CPS data. ${ }^{1}$ Given data limitations, neither approaches a full Haig-Simons income definition, which would include income such as the imputed rent on owner-occupied housing, but both broaden the income definitions substantially compared to previous research. Burkhauser, Larrimore, Simon (2012) show that moving from a Piketty and Saez (2003) IRS tax record-based pre-tax, pre-transfer cash market income of tax unit measure to a more comprehensive CPS-based household size-adjusted post-tax, post-transfer cash income of persons measure substantially increases observed median income growth since 1979 and flattens the level of growth across the distribution. This is even more the case when they include the ex-ante value of employer- and government-provided health insurance. But while health insurance is the most substantial in-kind benefit, Burkhauser, Larrimore, and Simon (2012) do not consider other in-kind benefits and, because of CPS data limitations, they do not include capital gains. In contrast, the CBO (2012), using data from both the IRS and CPS, not only includes the ex-ante value of employer- and government-provided health insurance but also includes food stamps and school lunches in its measure of the household size-adjusted post-tax, post-transfer cash income of persons. But most importantly, the $\mathrm{CBO}$ also includes taxable realized capital gains based on IRS data. When doing so, they observe markedly faster income growth at the top of this income distribution measure.

CBO's decision to include taxable realized capital gains is consistent with other users of the IRS data (see, e.g. Piketty and Saez, 2003), since that is the measure of capital gains in the IRS dataset. Here we provide an alternative measure of capital gains that is more consistent with

\footnotetext{
${ }^{1}$ CBO (2011) provides a set of comprehensive income tables for income years 1979-2007. They changed their measure of the value of Medicare and Medicaid in CBO (2012) and updated some of their earlier results in supplemental tables to adjust for this change. In our discussion of the $\mathrm{CBO}$ comprehensive income measure, we most closely mirror this more recent series.
} 
the income principles laid out by Haig-Simons. This alternative approach includes capital gains at accrual, measured as the increase or decrease in the value of capital assets in each year regardless of whether that asset was sold for a taxable realized gain. ${ }^{2}$ In contrast, taxable realized capital gains include asset appreciation that may have occurred years or decades earlier as current income. This is because individuals can choose, through the timing of transactions, when to realize capital gains for tax purposes. Hence, income recorded as taxable realized capital gains this year may not be due to increases in net-wealth this year. Additionally, taxable realized capital gains exclude accrued gains this year from assets that are not recorded on this year's tax returns, either because the asset was not sold, was sold but held in a tax-sheltered account, or was carved out of the tax code (e.g. primary housing).

Here we crosswalk from a Piketty-Saez (2003) market income definition to the more comprehensive Burkhauser, Larrimore, Simon (2012) income measure excluding capital gains to the CBO (2012) measure including taxable realized capital gains. In doing so, we demonstrate the extent to which the inclusion of taxable realized capital gains as income drives the increase in income inequality observed by the CBO. We then show that shifting from a taxable realized capital gains to a yearly accrued measure of capital gains, more in the spirit of a Haig-Simons definition of income, produces markedly different income trends.

\section{Data and Methods}

Our primary data set is the public-use CPS, enhanced with cell-means from Larrimore et al. (2008) to overcome topcoding of high incomes. ${ }^{3}$ The CPS questionnaire directly captures all

\footnotetext{
${ }^{2}$ As noted by Auerbach (1989) and Roine and Waldenstrom (2011), the Haig-Simons income definition should include all capital gains in the year that they accrue, not just those that are realized.

${ }^{3}$ In addition to topcoding of high incomes, there is a known trend-break in the CPS data between 1992 and 1993 when the Census changed data collection procedures (Ryscavage, 1995; Jones and Weinberg, 2000; DeNavas-Walt, Proctor, and Smith, 2012). We control this break in all our series using a procedure similar to Atkinson, Piketty, and Saez (2011), Burkhauser et al. (2012), and Larrimore (forthcoming), where all series are adjusted upward prior to 1993 such that no changes are recorded in the year from 1992-1993.
} 
cash income, including transfer income, excluding capital gains (see Weinberg, 2006 for a full list of income sources included in the CPS primary income measure). The CPS also provides values or imputations for certain government in-kind benefits, including food stamps, housing subsidies, and school lunches. We include these values in our computation.

While the CPS does not capture the premiums paid for health insurance coverage, it does ask respondents whether they are insured and, if so, their source of coverage. The Census Bureau then imputes an ex-ante insurance value of health insurance for all covered persons based on their employer's or the government's cost of purchasing it. When doing so, however, the Census Bureau treats employer- and government-provided insurance differently. They impute the value of employer-provided insurance coverage to individuals at its full ex-ante cost. The Census Bureau determines the value of employer contributions by first asking individuals if they were covered by employer provided health insurance, and if their employer paid for all, part, or none of the cost of the plan. Then, individuals in the March CPS are statistically matched to those in the National Medical Care Expenditure Survey or Medical Expenditure Panel Survey, depending on survey year, based on a number of explanatory variables common to both. ${ }^{4}$ This statistical matching provides an imputation of the employer's contribution. We use this Census Bureau exante value of in-kind, employer-provided health insurance to the individual in our analysis.

In contrast to its treatment of employer-provided insurance, the Census Bureau imputes a fungible insurance value of Medicare and Medicaid to covered individuals, which is intended to represent the level of resources individuals would have spent on health insurance had it not been provided to them. The ex-ante value for Medicare and Medicaid is calculated as the respective

\footnotetext{
${ }^{4}$ These variables include: type of plan (family or individual), proportion of cost paid for by employer, earnings, full-time/parttime work status, industry, occupation, public or private sector, region, residence, and demographic characteristics.
} 
program's average outlay by state and risk class in the income year in question. ${ }^{5}$ For higher income individuals, the Census Bureau values insurance as this ex-ante value, just as was the case for employer-provided insurance. But for families that cannot meet basic food and housing requirements, the Census Bureau assumes that the family derives no value from the insurance, because the government provision of insurance frees up no income to be otherwise spent to purchase insurance on their own. This approach implicitly assumes that since such families cannot afford their basic needs, they would be unlikely to purchase this insurance at any price.

Such assumptions seem too strong. Simply because low-income individuals would forego insurance, if it were not provided to them, does not indicate that they receive no value from it. Rather it implies that their consumer surplus from its purchase is less than the consumer surplus from other purchases, given the same level of spending. For example, Anderson, Dobkin, and Gross (2012) observe that young adults with insurance have substantially higher healthcare utilization rates than those without insurance. Similarly, Baicker et al. (2013) observe that in the two years after a Medicaid lottery, those that receive Medicaid receive more preventative medical care and are dramatically less likely to experience catastrophic out-of-pocket medical costs than those who lose the lottery and remain uninsured. Even though Baicker et al. did not observe improved physical health outcomes for those with insurance, their increased utilization of medical services and decreased probability of catastrophic health expenses indicates that they receive at least some value from the receipt of Medicaid.

Following the approach taken in Burkhauser, Larrimore, and Simon (2012) and CBO (2012), we use the ex-ante insurance value for all individuals, regardless of whether the

\footnotetext{
${ }^{5}$ Medicare risk classes are (1) age 65 and older, and (2) blind and disabled. Medicaid risk classes are (1) age 65 and older, (2) blind and disabled, (3) age 21-64 nondisabled, and (4) age less than 21, nondisabled.
} 
insurance is government-provided or employer-provided. ${ }^{6}$ For high-income individuals, we use the Census-imputed values in our measure of government insurance. For low-income individuals, we follow the Census Bureau imputation formula but do not replace these values with a zero insurance value.

Although the CPS captures or imputes most sources of income, the Census Bureau does not inquire about tax credits, tax liabilities, or capital gains. ${ }^{7}$ We supplement the CPS data with imputed and matched data as described below.

To impute tax credits and liabilities, we use the NBER TaxSim 9.0 to estimate federal and state income tax liabilities, including FICA and SECA taxes, based on the tax laws in effect in each year (see Feenberg and Coutts, 1993 for an overview of the NBER TaxSim program). Since the CPS samples households rather than tax filing units, we divide each household into tax units prior to imputing tax liabilities. We perform this division using the procedure described in Burkhauser et al. (2012), which mirrors the Piketty and Saez (2003) definition of potential tax units. We consider all single individuals age 20 and over, married couples, and divorced or widowed individuals to be independent tax units. We consider never-married children under the age of 20 to be dependents and assign them to the tax unit of their parent or guardian. ${ }^{8}$

Finally, for capital gains, we separately employ two procedures, one for taxable realized capital gains and one for yearly-accrued capital gains. For taxable realized capital gains, we array all tax-units into percentiles of taxable income in the CPS data in each year. Auten and Gee

\footnotetext{
${ }^{6}$ In their earlier work, CBO (2011) used the Census fungible value measure to value health insurance, but revised their approach in their subsequent work, CBO (2012)

${ }^{7}$ In 1992 the Census Bureau began imputing taxable realized capital gains in the CPS data. This series was updated in 2004 (see O'Hara, 2004). However, when we compared the distribution of realized taxable capital gains across our distribution of tax units in the CPS data to those from the actual 2007 IRS tax records, we found that the CPS results were much less concentrated at the top of the distribution. Hence, we decided to impute the capital gains data directly based on the administrative tax records rather than use the CPS imputation.

${ }^{8}$ In the small number of cases where never-married individuals under age 20 live in a household without a parent or guardian, we assign them to the tax unit of the household's primary family or the oldest adult in the household when there is no primary family. Only if the household has no adults over age 20 are they considered their own tax unit.
} 
(2009) observe that over 90 percent of working-age adults and over 85 percent of all adults over age 25 file a tax return. Nevertheless, it is important to account for non-filers in tax data when matching across the CPS and IRS datasets. Therefore, within each income percentile, we assign tax units a probability of filing a tax return based on the distribution of non-filers in the taxable income distribution excluding capital gains from the Joint Committee on Taxation 2007 Individual Tax Model (See Joint Committee on Taxation, 2011 for details). The vast majority of non-filers are individuals at the lower tail of the taxable income distribution, below the legal filing limit. Since the distribution of non-filers is not available in all years, we assume a constant distribution of non-filers in all years.

Among imputed filers in the CPS data, we again rank tax units by taxable income into percentiles. We perform a similar ranking on the IRS tax return data for each year. We then input the taxable realized capital gains for each tax unit in the CPS data as the mean taxable realized capital gains for tax units in the same percentile of the taxable income distribution in the tax return data, assuming that non-filers have no taxable realized capital gains.

We implement a similar matching procedure for yearly-accrued capital gains using the Survey of Consumer Finances (SCF) data. From the SCF, we obtain for each percentile of the distribution the mean total assets and asset allocation in both taxable and non-taxable accounts. However, because of a major break in the ability of the SCF data to capture wealth before and after 1989, for consistency we only compare our yearly-accrued capital gains estimates for 1989 onward. Following Smeeding and Thompson (2010) we impute accrued capital gains from stocks as the appreciation in the Dow Jones Industrial Average in the year times the assets held in stocks and mutual funds. Unlike Smeeding and Thompson (2010), however, for this measure and for our capital gains from real estate and privately held businesses, we use the single-year 
level of appreciation rather than an average across multiple years to more closely reflect the single-year Haig-Simons income growth measure.

While the SCF asset data include information on bond holdings along with holdings of stocks and mutual funds, we do not estimate capital gains from bonds. The primarily return from bonds for most bond holders is in the interest they pay rather than in capital gains. And the yearly change in accrued capital gains on those bonds will depend on their fixed lifespans.. Hence, unlike stocks where realized capital gains per year can be relatively easily estimated by assuming a given return on all stocks held in that year, there is no obvious way to link an average return on a Bond Index, to the information the SCF provides on the bond holdings of individuals.. So we do not include capital gains on bonds in our analyses. ${ }^{9}$

In addition to estimating capital gains from public equity investments, we also estimate capital gains from personal business ownership of non-public companies. Such private businesses are an important source of wealth and income for high-income individuals, As is the case for investment accounts, the SCF inquires about the value of privately held businesses, allowing us to use the same technique as above to match to the CPS data based on income percentile. However, since these firms are not traded on a public market, it is a substantial challenge to determine their rate of return. Moskowitz and Vissing-Jorgensen (2002) observe that the return to private equity investing is similar to that of investing in publicly held corporations and that these rates of return are highly correlated. Hence we assume the growth rate for privately held corporations matches that of public corporations. But given the findings of Davis et al. (2007) that employment growth at privately held firms is more volatile than at

\footnotetext{
9 To test the sensitivity of excluding capital gains on our measures of capital gains, we replicated all our results including an estimate of bond capital gains. We calculated bond capital gains as bond holdings times the annual rate of return on the Vanguard Bond Fund (VBMFX), which follows the Barclay's Capital Aggregate Bond Index. In estimating the bond rate of return, we excluded dividend payment from the return on the index in an attempt to minimize double counting of interest income. When doing so, we obtained quintile income growths from $1989-2007$ within one percentage point of those we provide in our main results for all quintiles. Therefore, it does not appear that the inclusion or exclusion of bond capital gains greatly impacts our results.
} 
publicly held firms, we recognize that there are differences between firms with different ownership structures and conduct sensitivity analyses with regards to the capital gains accrual rate for privately held businesses.

While our measure is plausibly the best currently available for imputing yearly-accrued capital gains on investments, we acknowledge that the lack of available data on capital gains accruals limits its precision. Most importantly, when imputing yearly-accrued capital gains we assume that all investments receive the ordinary rate of return. Hence we will not capture extranormal returns received by some individuals on their investments. This may be of particular concern for private equity investors who generate larger returns on investments through purchasing entire companies and reforming their production process or business model. Our yearly-accrued capital gains measure will understate extra-normal returns on such investments. However, this will only impact our trends in top income shares to the extent that the frequency or the size of these investments changes over time.

In addition to imputing capital gains from investments, we impute capital gains on primary housing to reflect gains in wealth resulting from real estate holdings. Since only homeowners can obtain housing capital gains, we use the same matching technique for homeowners in the CPS to homeowners in the SCF to obtain an estimate of house values by income percentile. We then impute housing capital gains as the growth in the House Price Index of the Federal Housing Finance Agency (FHFA) times the estimated home value. ${ }^{10}$ Importantly,

\footnotetext{
${ }^{10}$ As a sensitivity test we also used S\&P 500 data to impute our measure of investment returns and the Case-Shiller Home Price Index as our measure of real estate returns. The overall trends for the S\&P 500 is similar to that for the Dow Jones, but since S\&P 500 growth in 2007 was below that of the Dow Jones Index, income growth from 1999 through 2007 is lower when using the S\&P. For housing prices, the Case-Shiller index is more volatile than the FHFA index and observed a more marked decline in home values in 2007. Hence the imputed incomes of homeowners when using Case-Shiller were lower in 2007 than the values we report. This particularly impacted the income growth for the bottom quintile where the ratio of home values to income is highest. Nevertheless, for both the housing and equity measures, the alternate specifications strengthened the finding that the income growth for the top quintile relative to the middle quintile is slower when using accrued capital gains than when using realized capital gains. Results using these alternate specifications are available in Appendix Tables 1 and 2.
} 
since the SCF does not include state or locality information, we base all of our housing capital gains on national estimates of home values and home price appreciation. Hence we miss the substantial importance of local housing markets. Nevertheless, in the absence of local identifiers this is the best available information for imputing housing capital gains. It is similar to the method Smeeding and Thompson (2010) use to impute accrued housing capital gains.

\section{Results}

Table 1 compares income growth by quintile and for the top 5 percent across several common income definitions over the entire three-business cycle period from 1979-2007. It allows us to cross-walk from the relatively narrow Piketty and Saez-based market income of tax units definition, which excludes taxable realized capital gains, in column 1 to the more comprehensive CBO (2012)-based, household size-adjusted, post-tax post-transfer income of person income definition, including in-kind income and taxable realized capital gains, in column $4 .{ }^{11}$ We chose 1979 and 2007 as our comparison years because they are peak income years of business cycles and avoid conflating business cycle effects with long-term trends. Limitations in separately observing the income held by the top 1 percent in the public use CPS data we use here prevent us from providing trends in their distribution.

\section{[Insert Table 1 About Here]}

The first column reports mean income growth using a Piketty-Saez-style market income of tax unit income measure. Using this measure, which is typical for those using solely IRS data, the rich have gotten richer (37.9 percent increase for the top 5 percent), the poor have gotten

\footnotetext{
${ }^{11}$ In their original work, Piketty and Saez (2003) primarily focus on taxable income net of taxable realized capital gains. Burkhauser et al. (2012) show that CPS data can track this Piketty and Saez (2003) measure of the market income of tax units. In their more recent work, Piketty and Saez (see for example Atkinson, Piketty and Saez, 2011) focus more on taxable income including taxable realized capital gains. As we will show, this makes a dramatic difference in the growth of income among upper income groups.
} 
poorer (33 percent decline in the bottom quintile), and the middle has stagnated (2.2 percent increase in the middle quintile). However this income definition does not include transfers, taxes, or capital gains. ${ }^{12}$

Column 2, which is more in keeping with CPS-based research, broadens the income definition to include cash-transfers and expands the sharing unit to the household to reflect the sharing of resources by cohabiting couples and other householders who do not file a collective tax return (see Gottschalk and Danziger, 2005; Smeeding, Rainwater, and Burtless, 2001; and Burkhauser et al., 2011 for examples of research using similar definitions). In keeping with the traditional inequality literature, it focuses on the individual as the unit of analysis and adjusts for household size to reflect returns to scale of larger households. ${ }^{13}$ When doing so, income growth accelerates for all quintiles, but especially for the bottom quintile where mean income growth is now 9.9 percent, and in the middle where income increases by 22.8 percent or ten times the growth of market income found in column 1 . This is partially because government transfers are primarily directed to individuals that otherwise have lower than average pre-transfer incomes. But it also reflects the growth of cohabiting couples and of adult children living with their parents who share in the resources of others in their household-a behavioral change not captured by focusing solely on the market income of a tax unit unadjusted for the number of people in that tax unit.

A justifiable concern with this traditional income measure used by CPS researchers is that it includes as income some of the benefits received by individuals from the government, but does not include the taxes used to pay for them. Additionally, such a measure selectively

\footnotetext{
${ }^{12}$ Of the 22 country studies using income tax records discussed in Atkinson, Piketty and Saez (2011), the majority do not have data on realized capital gains and hence do not use this source of income in their estimations of top income.

${ }^{13}$ See Gottschalk and Smeeding (1997) for an early review of this literature and Burkhauser et al. (2012) for further discussion of size-adjusting household income and a more detailed breakdown of Column 1 to Column 2 changes attributable to the broader income definition, the larger sharing unit, and the size-adjustment.
} 
includes only some transfers, excluding both non-cash transfers and transfers administered through the tax code. Column 3 expands the income definition to reflect income post-tax liabilities and the presence of in-kind transfers and benefits. Converting to a post-tax income measure reduces the income of those with positive tax liabilities but increases the income for those receiving refundable credits such as the Earned Income Tax Credit (EITC)— the largest means-tested anti-poverty cash transfer program in the United States (Ben-Shalom, Moffitt, and Scholz, 2011). This column also incorporates several of the most important sources of in-kind benefits and government transfers: employer- and government-provided health insurance, food stamps, housing subsidies, and subsidized school lunches. To avoid double counting, we do not include another important in-kind benefit, defined-benefit pension contributions, at accrual, since they are included in the CPS data at the point of payout in retirement. We also do not include the yearly-accrued value of Social Security contributions, for the same reason.

The inclusion of taxes—because they have fallen as a share of income, especially at higher income levels—and in-kind benefits-because they have risen as a share of income, especially at lower income levels-increases income growth throughout the distribution. But it does so most, among the bottom two quintiles. As a result income growth between 1979 and 2007 is remarkably similar for each of the bottom four quintiles. The top quintile and the top 5 percent continue to grow faster, 54.0 and 68.9 percent respectively (column 3), but the gap in growth between them and the bottom quintile is dramatically smaller than the gap using a Piketty-Saez style cash market income of tax unit measure of income.

The final column of Table 1 reports results adding taxable realized capital gains, which is the approach used by the CBO (2012), to incorporate capital gains information. When doing so, we mirror the income growth patterns that they observe. Since the majority of realized capital 
gains are accrued by individuals with greater asset levels and greater incomes, income growth patterns since 1979 dramatically diverge relative to column 3 for higher income groups. Growth in the top quintile and among the top 5 percent is now 83.1 and 136.7 percent respectively while growth in the bottom three quintiles remains approximately the same.

Given our general agreement with the CBO findings on income growth by quintile when using this income measure between 1979 and 2007, we now report income growth for each single business cycle since 1979 in Panels A, B, and C of Table 2. Panel D provides the Gini coefficient for the peak-year of each business cycle since 1979, which offers a summary level of inequality at the peak of each business cycle. ${ }^{14}$

\section{[Insert Table 2 about here]}

When doing so, even when using the measure of income including taxable realized capital gains in column 4, we observe that while income inequality has grown across all business cycles, the majority of that inequality growth occurred in the 1980s. There was somewhat less inequality growth in the 1990s and very little in the 2000s.

In the 1980s business cycle, the top 5 percent of the income distribution saw their income grow by 55.6 percent, over 4.5 times the 11.7 percent growth in the middle quintile and over 20 times the 2.4 percent growth in the bottom quintile. In the 1990s, the growth pattern was Ushaped, with the bottom quintile's income growing faster than those in the middle. While income growth at the bottom and in the middle of the distribution was slower than for those at the top, the difference was less extreme than in the 1980s_-income growth was 43.4 percent for the top 5 percent versus 21.8 percent for the bottom and 16.4 percent for the middle quintile.

\footnotetext{
${ }^{14}$ We base the starting and ending years of business cycles on the peaks in median size-adjusted household income of persons (Burkhauser, Larrimore, and Simon, 2012; Daly and Valletta, 2006; and Karoly and Burtless, 1995, each use similar definitions). These years often correspond to the last full year of macroeconomic growth as defined by the NBER. However, in cases such as the 2000-2007 business cycle where the macroeconomic decline began in December 2007, the end-year here is defined as 2007, when median size-adjusted household income peaked.
} 
In contrast to the previous two periods where income growth was unequal but relatively rapid for most groups, in the early 2000s income growth was relatively equal but slow across all quintiles. Income grew between 5 and 7 percent over the period, throughout the distribution with the top two quintiles experiencing slightly faster growth than the bottom three.

We find a similar pattern in our Gini coefficients in Panel D. Using this summary inequality measure of CBO-style income, inequality increased from 0.303 to 0.359 (an 18 percent increase) in the 1980s business cycle and from 0.359 to 0.380 (a 6 percent increase) in the 1990s business cycle. But in the 2000s business cycle, it grew by just 0.8 percent to 0.383 . So while inequality remains at an elevated level, even when considering the income definition including taxable realized capital gains, inequality did not increase dramatically over the 2000s business cycle.

Including accrued capital gains

The results using the income definition including realized capital gains seem to validate the claim that inequality (fueled by a major increase in income at the top) has risen dramatically over the period 1979-2007. This increase far exceeds inequality growth in our comprehensive post-tax, post-transfer measure of income excluding all capital gains from column 3 that shows that inequality fell slightly in the 1990s and remained constant in the 2000s.

However, as previously noted taxable realized capital gains deviate from the spirit of Haig-Simon comprehensive income. In particular, including taxable realized capital gains in this way will confound asset appreciation in earlier years but declared in this year with capital gains actually accrued in this year. Hence it will artificially delay the receipt of some capital gains income from when it should be counted under Haig-Simons principles. Additionally, it almost completely ignores housing capital gains due to the $\$ 500,000$ exclusion from taxation of housing 
capital gains for primary residences owned by a married couple and also ignores capital gains held in non-taxable accounts. Since housing assets represent the largest single asset of many middle class households, the failure of tax-based data to capture the capital gains of these taxsheltered assets will likely distort the impact of capital gains from a Haig-Simons perspective. Thus, to more closely reflect Haig-Simons’ principles in the treatment of capital gains, in Table 3 we now turn our attention to how inequality trends would change using yearly-accrued capital gains of taxable and tax-sheltered assets rather than just realized taxable gains.

[Insert Table 3 about here]

This analysis relies on the Survey of Consumer Finance (SCF), but since the SCF data prior to 1989 are not comparable with SCF data thereafter, we only consider income growth using this measure for the two-business-cycle period from 1989-2007. Additionally, since the SCF is a triennial survey, it is only available for select years, which do not include the 2000 business cycle peak. Thus, we only provide full business-cycle results for the two-business-cycle period. However, we will discuss the triennial top income share results for each available year between 1989 and 2007 in greater depth below. For comparability, we provide each of the previously discussed series for this two-business-cycle period.

In the two business cycles since 1989, when looking solely at market income of tax units, the rich get richer, the poor get poorer, and the middle class stagnate. But over the peak years of these business cycles, growth is considerably smaller for the top income quintile and the top 5 percent than it was when considering the three-business-cycle period since 1979. Once again this story changes when we expand our income definition in columns 2 and 3. Income growth across all quintiles since 1989, and even in the top 5 percent, narrows remarkably when compared to the extended period since 1979 seen earlier. In column 3, growth in the bottom quintile is greatest 
and growth among the top 5 percent is smallest over this period. It is only when we add taxable realized capital gains in column 4 that income growth in the top quintile and among the top 5 percent is greater than that in the bottom four quintiles.

But in column 5 when we include yearly-accrued capital gains excluding housing gains and private business gains, instead of taxable realized capital gains, the inclusion of these gains slows income growth in all but the bottom quintile of the distribution. Thus, when using this measure that is more in line with Haig-Simon's income principles, the top quintile of the distribution had the least growth in income from 1989 through 2007 while the bottom quintile of the distribution had the most. Measured in this way income inequality fell between 1989 and 2007.

How is it possible that the choice of treatment of capital gains can have such a dramatic difference? It results from both the timing of realizing gains and from the likelihood of assets appearing in taxable accounts for individuals at different points in the income distribution.

Table 4 presents the mean value of equity investments in taxable and non-taxable accounts in the SCF data for each quintile of the income distribution (based on a household sizeadjusted, post-tax, post-transfer, cash plus in-kind income of persons measure of income-our column 3 income measure in Table 3) in 1989 and 2007. This table illustrates that while equity holdings have increased throughout the distribution, they have increased at a faster pace for those at the lower end of the distribution than for those at the top. For example, in the bottom quintile mean equity investment holdings (column 3 in Table 4) grew over 7-fold from \$3,677 in 1989 to $\$ 28,786$ in 2007. This compares to the top quintile where mean equity holdings in 2007 were 3.5 times their 1989 amount $(\$ 381,423$ versus $\$ 108,702)$.

[Insert Table 4 about here] 
Further, this increase in equity holdings has disproportionately occurred in tax-sheltered accounts (column 2). The use of tax-sheltered accounts increased throughout the distribution over this period. By 2007 over a quarter of investments for equity holdings in each quintile of the distribution were tax-sheltered, with greater percentages in the middle of the distribution (column 4). Thus, the focus on taxable realized capital gains will miss this increasingly important source of capital gains income. In particular, to the extent that a larger fraction of equities are held in tax-sheltered accounts among the middle- and lower-quintiles, researchers focusing on just taxable income will disproportionately miss income received by these middle- and lowerincome individuals.

Although tax-sheltered accounts are an important source of missed income-growth for the bottom of the distribution relative to the top, at least as important for reconciling the divergent findings of using taxable realized capital gains and yearly accrued capital gains is the trend in capital gains from stocks over time. In particular, the appreciation of the Dow Jones Industrial Average in 1989 was a substantial 27 percent, compared to a tepid 6.4 percent in 2007. Thus, the lower growth rate means that one should expect a lower level of accrued gains, other than for individuals whose asset holdings in 2007 were dramatically greater than in 1989.

In part, this simply represents the volatility inherent in an accrued capital gains measure, as illustrated in Figure 1, which depicts the real appreciation in the Dow Jones Industrial Average in each year since 1979. However, while the series is volatile and a comparison of different years would alter the results, it also is a reflection of the slower growth in accrued capital gains in the 2000s compared to either the 1980s or 1990s. The inflation-adjusted average yearly growth in the Dow Jones Industrial Average was 8.2 percent over the 1980s business cycle (1980-1989), 11.2 percent over the 1990s business cycle (1990-2000), but only 1.1 percent 
over the 2000s business cycle (2001-2007). So accrued capital gains from equities in almost any year of the 2001-2007 business cycle will be lower than over the previous two business cycles.

\section{[Insert Figure 1 about here]}

Given the lower stock market returns in the 2000s, it is not surprising that the rapid accrual of capital gains occurred in the 1980s and 1990s rather than in the 2000s. This pattern can be quite different from the one that results when focusing on taxable realized capital gains, since the appreciation of investments in the 1980s and 1990s may not appear on income tax returns until later. As a result, the high taxable realized capital gains income observed on tax returns today are not necessarily a reflection of higher current incomes in a Haig-Simons sense and, instead, are more likely to be a residual effect of previously accrued capital gains that are only now being realized.

Although the inclusion of yearly-accrued capital gains from investment accounts in column 5 of Table 3 is more in keeping with Haig-Simons principles than using taxable realized capital gains, it still excludes a primary source of wealth accumulation for many Americans - the increase in value of their primary residence. In column 6 of Table 3 we expand our income definition to include yearly-accrued capital gains from owner-occupied housing.

As was the case with yearly-accrued capital gains from equity investments, the real accrued capital gains from housing in 2007 (-4.7 percent) was below that seen in 1989 (0.7 percent). ${ }^{15}$ Thus, including this source of income should result in lower levels of observed income for homeowners in 2007 than was the case in column 5 of Table 3, but the drop in home prices is likely to affect growth at lower income levels as well as at upper income levels.

Table 5 shows why this is likely to be the case. Individuals with higher incomes are both

\footnotetext{
${ }^{15}$ Annual accrued gains from housing using the FHFA data is available upon request from the author.
} 
more likely to own a home (columns 1 and 3) and, conditional on owning a home (columns 2 and 4), are more likely to own expensive homes. As a result, the absolute decline in income from including housing capital gains should be larger for those in the upper tail of the distribution than for those in the lower tail. But, relative to their total income excluding housing gains, the home value should be smaller for the top quintile relative to their income so the impact on percentage income growth will be smaller at the top of the distribution.

\section{[Insert Table 5 about here]}

As column 6 of Table 3 shows, this is the case. Income growth slows for all income quintiles relative to column 5 of Table 3. But it slows more for those lower in the distribution17.6 percentage points for the bottom quintile (from 32.2 percent to 14.6 percent) — than it does for those near the top-11.2 percentage points for the top quintile (from 12.8 percent to 1.6 percent).

Nevertheless, similar to our column 3 of Table 3 results where we exclude all capital gains, the income growth for the top quintile of the distribution was the slowest from 1989 through 2007 and the income growth for the bottom quintile was the largest. Further, the top 5 percent of the income distribution experienced a decline in their income, while each of the lower quintiles experienced modest income growth. These results not only dissipate but reverse the evidence supporting dramatic increases in income inequality powered by major increases in capital gains when measured by taxable realized capital gains.

In the final column of Table 3, we add in a final element of accrued capital gains- those that occur on closely held businesses. In doing so, we emphasize the increased uncertainty around this estimate of accrued capital gains on privately held businesses given the lack of a public market for such companies. In estimating these accrued capital gains, since investing in 
privately held companies is riskier than investing in public corporations (Moskowitz and Vissing-Jorgensen, 2002), one may expect private companies to have a greater rate of return to account for the additional risk. But despite this expectation, Moskowitz and Vissing-Jorgensen (2002) observe there is a strong correlation between the average rates of return on public and private companies, and that the rate of return for private equity investments are similar to those for public equity. Therefore, in estimating the rates of return when including accrued gains on privately held businesses, we assume that the rate of return in each year matches that of publicly traded corporations. ${ }^{16}$

Including the accrued capital gains from privately held businesses has very little effect on the income growth of the bottom quintile of the distribution from 1989 through 2007, but income growth for all the higher quintiles is slower than that for the previous series. In fact, among the top quintile top incomes actually fell. This is because private business ownership is largely concentrated among the top quintiles of the distribution and, as can be seen in Table 6 (columns 1 and 3). Furthermore, among business owners, individuals with higher pre-capital-gains incomes tend to own businesses with substantially higher valuations (columns 2 and 4). Given this concentration of business ownership wealth, the lower estimated rate of return on both public and private equity in 2007 compared to 1989 results in the further erosion of top incomes when including capital gains from privately held businesses. Since there is additional uncertainty regarding the rate of return on private equity, our preferred results in Table 3 are those from column 6, which excludes the capital gains on privately held businesses. Nevertheless, the results from including capital gains on privately held businesses appear to reinforce our primary

\footnotetext{
${ }^{16}$ Recognizing this uncertainty, we conducted a sensitivity analysis, assuming that the rate of return on private equity exceeds that observed for public equity by 2 percentage points per year. The results of such an analysis were similar, with the lower end of the distribution observing the greatest income growth since 1989. The results of this supplemental analysis are available from the authors upon request.
} 
observation that focusing on accrued capital gains presents a dramatically different picture than that observed when using taxable realized capital gains which are limited to assets which are taxable and more easily manipulated through market timing.

[Insert Table 6 about here]

\section{Annual Top Income Shares}

To better link our results to the top income literature, we show the trends in the share of all income held by the top 5 percent (Figure 2) and top quintile of the distribution over all available years between 1989-2007 across five alternative measures of income with and without capital gains. The first two are post-tax, post-transfer income including in-kind benefits but excluding all capital gains (column 3 from Table 3), which closely matches the income series from Burkhauser et al. (2011), and post-tax, post-transfer income including in-kind benefits and realized taxable capital gains (column 4 from Table 3), which closely matches the income series from CBO (2012).

The next three, like the CBO measure, also contain post-tax, post-transfer income including in-kind benefits. But rather than using taxable realized capital gains they offer alternative measures of capital gains that are more consistent with Haig-Simons principals: the first includes yearly-accrued capital gains from investments, excluding housing (column 5 from Table 3); the next yearly-accrued capital gains from investments and housing (column 6 from Table 3); and the last yearly-accrued capital gains from investments and housing including personally held businesses (column 7 from Table 3). Once again, because we are dependent on SCF data to estimate the three yearly-accrued capital gains measures, we have information only for every three years.

Our traditional measure of full income based on CPS data that excludes capital gains 
shows that the share of this income held by top income groups (either the top 5 or top 20 percent) has been remarkably stable over the entire period from 1989-2007. Because top income groups hold a disproportionate amount of assets in the U.S., it is not surprising that all four of our measures that include capital gains show a higher share of that income is held by top income groups in most years. But the pattern of growth in the share of full income captured by these four measures is quite different.

\section{[Insert Figure 2 about here] \\ [Insert Figure 3 about here]}

When we include taxable realized capital gains, the trend in top income shares is in line with the CBO (2012) observation that top income shares have increased over the past two decades and are now at or near their all-time peak. But that is not the case when using the three yearly-accrued realized capital gains series.

When using any of the accrued capital gains series, the top income share measures are noticeably more volatile, even with the qualification that they can only be observed for every third year due to the SCF limitations. But despite this volatility, valuable trends can be observed. The top income shares using accrued capital gains are above those seen when excluding capital gains or including realized capital gains in each of our four years of observation in the 1990s (1989-1998). There is a shift in this relationship in the 2000s. In 2001, accrued gains at the top fell, resulting in lower top income shares using the accrued gains method than is seen when using realized capital gains or excluding capital gains completely. But even in 2004 and 2007 the three series using accrued capital gains show top income shares at or below those using realized gains. This shift in the relationship between the top income series with different treatments of capital gains is consistent with the idea that recent taxable realized capital gains are, in part, the residual 
of gains from earlier years and do not reflect current capital gains income. ${ }^{17}$

Because of this time shifting for taxable realized capital gains, any of our accrued capital gains series-based top income share patterns vary from those based on realized taxable capital gains. We previously observed an increase in the top income shares since 1989 when including taxable realized capital gains. However, when using any of the yearly-accrued measures, the income shares of the top 5 and 20 percent of the distribution in each year of available data since 2000 were below those seen at the start of the series in 1989. So when we, based on Haig-Simons principles, include capital gains in the year they accrue, , top income shares are volatile but do not appear to have increased over the last 20 years.

\section{Conclusion}

When using the level and trend in income and its distribution as evidence in evidencebased tax law and fiscal policy making, it is important to understand the assumptions underlying the alternative measures of income we provide in our analysis. If income and its distribution were invariant across the most common measures of income we report here, then the choice of income measure would not greatly matter. But that is not the case. Hence for policy purposes it is critical to use a measure of income that is most consistent with the policy question being asked. For those focused on taxable income of tax units excluding taxable capital gains-a Piketty and Saez (2003) measure of market income, based on tax returns-undoubtedly income inequality has grown substantially in recent years, and the middle-class is struggling. The inclusion of taxable realized capital gains in income measures that are more inclusive-like the CBO (2012) measure using both tax returns and CPS data-reinforces this view of rising inequality, but it

\footnotetext{
${ }^{17}$ Additionally, in the long-run, one should expect fewer capital gains to be realized on tax returns than the total of accrued capital gains. This is partially because some gains are deferred until death, at which point there is a step-up in basis so no realized capital gains will be reported. Furthermore, since some capital gains, such as those on primary housing and Roth IRAs are tax exempt, these gains will never appear on tax returns.
} 
does so by including a measure of capital gains that misses the timing of capital gains accruals, as well as the increasing importance of realized and accrued capital gains in tax-sheltered accounts.

In contrast, when using our comprehensive income definition, that mirrors the CBO (2012) report but excludes all capital gains, we observe that incomes have risen throughout the distribution and since 1989 have largely risen uniformly throughout that distribution. Alternatively, following Haig-Simons principals, when we include capital gains on a yearlyaccrued basis, it increases the volatility of income trends but results in slower growth throughout the income distribution than when we exclude capital gains. This reflects lower capital gains accrual rates in the most recent business cycle compared to the proceeding business cycles. But it also shows that inequality did not rise in recent years. The top quintile of the income distribution had the slowest income growth from 1989 through 2007, while the bottom quintile had the fastest.

Recognizing the increased volatility of the accrued capital gains series and its triennial rather than annual availability, we acknowledge that this series comes with substantial limitations for researchers interested in observing current annual income and inequality trends. Additionally, since capital gains are an irregular source of income, some researchers may opt to avoid this volatility by excluding capital gains altogether-as the Census Bureau has traditionally done in their official income statistics (DeNavas-Walt, Proctor, and Smith 2012). However, should one wish to include capital gains, doing so based on yearly accrued capital gains is more appropriate than including only taxable realized capital gains. Using yearlyaccrued capital gains will include gains accruing in tax-sheltered accounts and avoid the timing problems that occur with the delayed realization of capital gains for tax filing purposes. As we 
show in this paper, this fuller measure of capital gains contradicts the notion that income inequality fueled by capital gains at the top end of the distribution has dramatically increased over the past two business cycles. 


\section{REFERENCES}

Anderson, M., C. Dobkin, and T. Gross. 2012. "The Effect of Health Insurance Coverage on the Use of Medical Services,” American Economic Journal: Economic Policy 4(1):1-27.

Atkinson, A.B., T. Piketty, and E. Saez. 2011. “Top Incomes in the Long Run of History,” Journal of Economic Literature 49(1), 3-71.

Auerbach, A.J. 1989. “Capital Gains Taxation and Tax Reform,” National Tax Journal 42(3): 391-401.

Auten, G., and G. Gee. 2009. "Income Mobility in the United States: New Evidence from Income Tax Data.” National Tax Journal 62(2): 301-328.

Baicker, K., S.L. Taubman, H.L. Hallen, M. Bernstein, J.H. Gruber, J.P. Newhouse, E.C. Schneider, B.J. Wright, A.M. Zaslavsky, and A.N. Finkelstein. 2013. “The Oregon Experiment-Effects of Medicaid on Clinical Outcomes," New England Journal of Medicine 368(18): 1713-1722.

Barthold, T. 1993. “How Should We Measure Distribution,” National Tax Journal 46(3): 29199.

Ben-Shalom, Y., R.A. Moffitt, and J.K. Scholz. 2011. "An Assessment of the Effectiveness of Anti-Poverty Programs in the United States,” NBER Working Paper No. 17042.

Burkhauser, R.V., S. Feng, S.P. Jenkins, and J. Larrimore. 2011. "Trends in United States Income Inequality Using the March Current Population Survey: The Importance of Controlling for Censoring,” Journal of Economic Inequality 9(3): 393-415.

Burkhauser, R.V., S. Feng, S.P. Jenkins, and J. Larrimore. 2012. "Recent Trends in Top Income Shares in the USA: Reconciling Estimates from March CPS and IRS Tax Return Data," Review of Economics and Statistics 94(2), 371-388.

Burkhauser, R.V., J. Larrimore, and K. Simon. 2012. “A Second Opinion on the Economic Health of the Middle Class,” National Tax Journal 61(1), 7-22.

Congressional Budget Office. 2011. Trends in the Distribution of Household Income between 1979 and 2007. U.S. Government Printing Office, Washington, DC.

Congressional Budget Office. 2012. The Distribution of Household Income and Federal Taxes, 2008 and 2009. U.S. Government Printing Office, Washington, DC. Supplemental data tables available online via: http://www.cbo.gov/publication/43373

Daly, M.C., and R.G. Valletta. 2006. "Inequality and Poverty in the United States: The Effects of Rising Dispersion of Men’s Earnings and Changing Family Behavior,” Economica 73(289), 75-98.

Davis, S.J., J. Haltiwanger, R. Jarmin, and J. Miranda. 2007. "Volatility and Dispersion in Business Growth Rates: Publicly Traded versus Privately Held Firms,” in NBER 
Macroeconomics Annual 2006, Vol. 21. eds. D. Acemoglu, K. Rogoff, and M. Woodford, 1782-1872. Cambridge, MA: MIT Press.

DeNavas-Walt, C., B.D. Proctor, and J.C. Smith. 2012. Income, Poverty, and Health Insurance Coverage in the United States: 2011. US Census Bureau Population Reports, P60-243, U.S. Government Printing Office, Washington, DC.

Gottschalk, P., and S. Danziger. 2005. "Inequality of Wage Rates, Earnings and Family Income in the United States, 1975-2002," Review of Income and Wealth 51(2), 231-254.

Gottschalk, P., and T.M. Smeeding. 1997. "Cross-National Comparisons of Earnings and Income Inequality,” Journal of Economic Literature 35, 633-687.

Feenberg, D., and E. Coutts. 1993. “An Introduction to the TAXSIM Model,” Journal of Policy Analysis and Management 12(1), 189-94, http://www.nber.org/ taxsim/

Joint Committee on Taxation. 2011. Summary of Economic Models and Estimating Practices of the Staff of the Joint Committee on Taxation JCX-46-11. U.S. Government Printing Office, Washington, DC.

Jones, A.F., and D.H. Weinberg. 2000. "The Changing Shape of the Nation's Income Distribution,” Current Population Reports, U.S. Census Bureau.

Karoly, L.A., and G. Burtless. 1995. "Demographic Change, Rising Earnings Inequality, and the Distribution of Personal Well Being, 1959-1989,” Demography 32(3), 379-405.

Larrimore, J. Forthcoming. “Accounting for United States Household Income Inequality Trends: The Changing Importance of Household Structure and Male and Female Labor Earnings Inequality," Review of Income and Wealth.

Larrimore, J., R.V. Burkhauser, S. Feng, and L. Zayatz. 2008. "Consistent Cell Means for Topcoded Incomes in the Public Use March CPS (1975-2007)," Journal of Economic and Social Measurement 33(2-3), 89-128.

Moskowitz, T.J. and A. Vissing-Jorgensen. 2002. "The Returns to Entrepreneurial Investment: A Private Equity Premium Puzzle?” American Economic Review 92(4), 745-778.

O’Hara, A. 2004. "New Methods for Simulating CPS Taxes.” U.S. Census Bureau Technical Working Paper.

Piketty, T., and E. Saez. 2003. “Income Inequality in the United States, 1913-1998,” Quarterly Journal of Economics 118(1), 1-39.

Roine, J., and D. Waldenstrom. 2011. "On the Role of Capital Gains in Swedish Income Inequality.” Review of Income and Wealth 58(3): 569-587.

Ryscavage, P. 1995. “A Surge in Growing Income Inequality?” Monthly Labor Review 118(8), 51-61. 
Smeeding, T., L. Rainwater, and G. Burtless. 2001. "United States Poverty in a Cross-National Context," FOCUS Institute for Research on Poverty 21(3), 50-54.

Smeeding, T.M., and J.P. Thompson. 2010. "Recent Trends in the Distribution of Income: Labor, Wealth, and More Complete Measures of Well Being," Political Economy Research Institute Working Paper Series, No. 25.

Weinberg, D.H. 2006. “Income Data Quality Issues in the CPS,” Monthly Labor Review 129(6): 38-45. 
TABLE 1-MEAN INCOME GROWTH BY QUINTILE, 1979-2007

\begin{tabular}{|c|c|c|c|c|}
\hline & (1) & (2) & (3) & (4) \\
\hline & $\begin{array}{c}\text { Tax-unit } \\
\text { unadjusted cash } \\
\text { market income }\end{array}$ & $\begin{array}{l}\text { Household size- } \\
\text { adjusted pre-tax, } \\
\text { post-transfer cash } \\
\text { income }\end{array}$ & $\begin{array}{l}\text { Household size- } \\
\text { adjusted post-tax, } \\
\text { post-transfer } \\
\text { income plus in-kind } \\
\text { income }\end{array}$ & $\begin{array}{l}\text { Column (3) plus } \\
\text { realized taxable } \\
\text { capital gains }\end{array}$ \\
\hline Bottom Quintile & -33.0 & 9.9 & 31.8 & 31.1 \\
\hline $2^{\text {nd }}$ Quintile & 0.7 & 15.6 & 31.3 & 32.0 \\
\hline Middle Quintile & 2.2 & 22.8 & 34.4 & 36.7 \\
\hline $4^{\text {th }}$ Quintile & 12.3 & 29.2 & 38.8 & 42.7 \\
\hline Top Quintile & 32.7 & 42.0 & 54.0 & 83.1 \\
\hline Top 5\% & 37.9 & 48.7 & 68.9 & 136.7 \\
\hline
\end{tabular}

Source: Author calculations based on March CPS data merged with SOI tax return data and NBER TaxSim results. 
TABLE 2- GINI COEFFICIENTS AND MEAN INCOME GROWTH BY QUINTILE FOR EACH BUSINESS CYCLE FROM 1979-2007

\begin{tabular}{|c|c|c|c|c|}
\hline & $\begin{array}{c}\text { Tax-unit } \\
\text { unadjusted cash } \\
\text { market income }\end{array}$ & $\begin{array}{l}\text { (2) } \\
\text { Household size- } \\
\text { adjusted pre-tax, } \\
\text { post-transfer cash } \\
\text { income }\end{array}$ & $\begin{array}{c}\text { (3) } \\
\text { Household size- } \\
\text { adjusted post-tax, } \\
\text { post-transfer } \\
\text { income plus in-kind } \\
\text { income }\end{array}$ & $\begin{array}{l}\text { (4) } \\
\text { Column (3) plus } \\
\text { realized taxable } \\
\text { capital gains }\end{array}$ \\
\hline \multicolumn{5}{|c|}{ Panel A: 1979-1989 } \\
\hline Bottom Quintile & -0.2 & 0.0 & 4.3 & 2.4 \\
\hline $2^{\text {nd }}$ Quintile & -0.2 & 4.3 & 7.0 & 6.4 \\
\hline Middle Quintile & 0.0 & 9.1 & 11.8 & 11.7 \\
\hline $4^{\text {th }}$ Quintile & 4.0 & 12.9 & 15.7 & 15.6 \\
\hline Top Quintile & 17.6 & 23.4 & 29.4 & 33.1 \\
\hline Top 5\% & 25.6 & 32.0 & 44.6 & 55.6 \\
\hline \multicolumn{5}{|c|}{ Panel B: 1989-2000 } \\
\hline Bottom Quintile & 17.8 & 17.2 & 20.6 & 21.8 \\
\hline $2^{\text {nd }}$ Quintile & 11.7 & 13.5 & 16.7 & 17.9 \\
\hline Middle Quintile & 7.5 & 13.1 & 14.6 & 16.4 \\
\hline $4^{\text {th }}$ Quintile & 10.7 & 13.3 & 12.6 & 15.5 \\
\hline Top Quintile & 14.7 & 16.2 & 13.5 & 29.2 \\
\hline Top 5\% & 14.4 & 16.5 & 13.9 & 43.4 \\
\hline \multicolumn{5}{|c|}{ Panel C: 2000-2007 } \\
\hline Bottom Quintile & -43.0 & -6.2 & 4.8 & 5.1 \\
\hline $2^{\text {nd }}$ Quintile & -9.8 & -2.4 & 5.2 & 5.2 \\
\hline Middle Quintile & -4.9 & -0.4 & 4.9 & 5.1 \\
\hline $4^{\text {th }}$ Quintile & -2.5 & 1.0 & 6.6 & 6.9 \\
\hline Top Quintile & -1.6 & -1.0 & 4.8 & 6.5 \\
\hline Тор 5\% & -4.0 & -3.3 & 2.6 & 6.1 \\
\hline \multicolumn{5}{|c|}{ Panel D: Gini Coefficients } \\
\hline 1979 & 0.536 & 0.384 & 0.301 & 0.303 \\
\hline 1989 & 0.565 & 0.423 & 0.346 & 0.359 \\
\hline 2000 & 0.571 & 0.427 & 0.338 & 0.380 \\
\hline 2007 & 0.584 & 0.430 & 0.338 & 0.383 \\
\hline
\end{tabular}

Source: Author calculations based on March CPS data merged with SOI tax return data and NBER TaxSim results. 
TABLE 3-MEAN INCOME GROWTH BY QUINTILE, 1989-2007

\begin{tabular}{|c|c|c|c|c|c|c|c|}
\hline & (1) & (2) & (3) & (4) & (5) & (6) & (7) \\
\hline & $\begin{array}{c}\text { Tax-unit } \\
\text { unadjusted } \\
\text { cash market } \\
\text { income } \\
\end{array}$ & $\begin{array}{l}\text { Household size- } \\
\text { adjusted pre-tax, } \\
\text { post-transfer cash } \\
\text { income }\end{array}$ & $\begin{array}{l}\text { Household size- } \\
\text { adjusted post-tax, } \\
\text { post-transfer } \\
\text { income plus in- } \\
\text { kind income }\end{array}$ & $\begin{array}{l}\text { Column (3) plus } \\
\text { realized taxable } \\
\text { capital gains }\end{array}$ & $\begin{array}{l}\text { Column (3) plus } \\
\text { accrued capital } \\
\text { gains from public } \\
\text { investments }\end{array}$ & $\begin{array}{l}\text { Column (3) plus } \\
\text { accrued capital } \\
\text { gains, including } \\
\text { housing }\end{array}$ & $\begin{array}{c}\text { Column (3) plus } \\
\text { accrued capital } \\
\text { gains, including } \\
\text { housing and } \\
\text { privately held } \\
\text { businesses }\end{array}$ \\
\hline Bottom Quintile & -32.9 & 9.9 & 26.4 & 28.0 & 29.4 & 12.9 & 15.2 \\
\hline $2^{\text {nd }}$ Quintile & 0.8 & 10.8 & 22.7 & 24.0 & 22.9 & 8.5 & 3.1 \\
\hline Middle Quintile & 2.3 & 12.6 & 20.2 & 22.3 & 18.1 & 6.1 & -0.5 \\
\hline $4^{\text {th }}$ Quintile & 8.0 & 14.4 & 20.0 & 23.5 & 17.0 & 5.5 & -0.6 \\
\hline Top Quintile & 12.9 & 15.1 & 19.0 & 37.5 & 10.9 & -0.7 & -14.5 \\
\hline Top 5\% & 9.9 & 12.7 & 16.8 & 52.2 & 6.7 & -4.5 & -25.3 \\
\hline
\end{tabular}

Source: Author calculations based on March CPS data merged with SOI tax return data, Survey of Consumer Finance Data, and NBER TaxSim results 
TABLE 4- INFLATION-ADJUSTED INVESTMENT ASSETS BY QUINTILE OF HOUSEHOLD SIZE-ADJUSTED COMPREHENSIVE INCOME, EXCLUDING ALL CAPITAL GAINS IN 1989 AND 2007

\begin{tabular}{lcccc}
\hline & $\begin{array}{c}\text { Taxable } \\
\text { Investment } \\
\text { Assets }\end{array}$ & $\begin{array}{c}\text { Tax Sheltered } \\
\text { Investment Assets }\end{array}$ & $\begin{array}{c}\text { Total Investment } \\
\text { Assets }\end{array}$ & $\begin{array}{c}\text { \% of Investment } \\
\text { Assets in Tax } \\
\text { Sheltered Accounts }\end{array}$ \\
\hline Panel A: 1989 & 3,013 & 664 & 3,677 & 18.0 \\
Bottom Quintile & 8,302 & 1,297 & 9,599 & 13.5 \\
$2^{\text {nd }}$ Quintile & 11,587 & 3,208 & 14,795 & 21.7 \\
Middle Quintile & 17,892 & 5,634 & 23,527 & 23.9 \\
$4^{\text {th }}$ Quintile & 87,544 & 21,158 & 108,702 & 19.5 \\
Top Quintile & & & & \\
& & & & 32.1 \\
Panel B: 2007 & 19,534 & 9,252 & 28,786 & 34.9 \\
Bottom Quintile & 25,632 & 13,738 & 39,370 & 38.6 \\
$2^{\text {nd }}$ Quintile & 31,176 & 19,559 & 50,734 & 42.6 \\
Middle Quintile & 41,303 & 30,683 & 71,985 & 25.4 \\
$4^{\text {th }}$ Quintile & 284,595 & 96,828 & 381,423 & \\
Top Quintile & & & & \\
\hline
\end{tabular}

Source: Author calculations based on Survey of Consumer Finance Data. Indexed to 2012 price levels using the CPI-U-RS. 
TABLE 5- HOMEOWNERSHIP AND INFLATION-ADJUSTED HOME VALUES BY QUINTILE OF HOUSEHOLD SIZEADJUSTED COMPREHENSIVE INCOME, EXCLUDING ALL CAPITAL GAINS IN 1989 AND 2007

\begin{tabular}{lcccc}
\hline & $\begin{array}{c}1989 \text { percent } \\
\text { homeowners }\end{array}$ & $\begin{array}{c}1989 \text { mean home } \\
\text { value of } \\
\text { homeowners }\end{array}$ & $\begin{array}{c}2007 \text { percent } \\
\text { homeowners }\end{array}$ & $\begin{array}{c}\text { 2007 mean home } \\
\text { value of } \\
\text { homeowners }\end{array}$ \\
\hline $\begin{array}{l}\text { Bottom Quintile } \\
2^{\text {nd }} \text { Quintile }\end{array}$ & 39.8 & 103,524 & 44.2 & 175,702 \\
Middle Quintile & 60.1 & 114,872 & 62.4 & 175,578 \\
$4^{\text {th }}$ Quintile & 71.5 & 119,157 & 74.2 & 184,892 \\
Top Quintile & 78.5 & 142,193 & 82.2 & 225,564 \\
\hline
\end{tabular}

Source: Author calculations based on Survey of Consumer Finance Data. Indexed to 2012 price levels using the CPI-U-RS. 
TABLE 6 - PRIVATE BUSINESS OWNERSHIP AND INFLATION-ADJUSTED BUSINESS VALUES BY QUINTILE OF HOUSEHOLD SIZE-ADJUSTED COMPREHENSIVE INCOME, EXCLUDING ALL CAPITAL GAINS IN 1989 AND 2007

\begin{tabular}{lcccc}
\hline & $\begin{array}{c}1989 \text { percent } \\
\text { private business } \\
\text { owners }\end{array}$ & $\begin{array}{c}1989 \text { mean } \\
\text { business value of } \\
\text { business owners }\end{array}$ & $\begin{array}{c}\text { 2007 percent } \\
\text { private business } \\
\text { owners }\end{array}$ & $\begin{array}{c}2007 \text { mean } \\
\text { business value of } \\
\text { business owners }\end{array}$ \\
\hline Bottom Quintile & 2.1 & 23,937 & 4.9 & 46,487 \\
$2^{\text {nd }}$ Quintile & 6.0 & 19,562 & 5.3 & 34,581 \\
Middle Quintile & 8.4 & 25,472 & 8.9 & 45,362 \\
$4^{\text {th }}$ Quintile & 12.7 & 36,918 & 13.1 & 96,707 \\
Top Quintile & 19.2 & 220,700 & 21.4 & 500,229 \\
\hline
\end{tabular}

Source: Author calculations based on Survey of Consumer Finance Data. Indexed to 2012 price levels using the CPI-U-RS. 


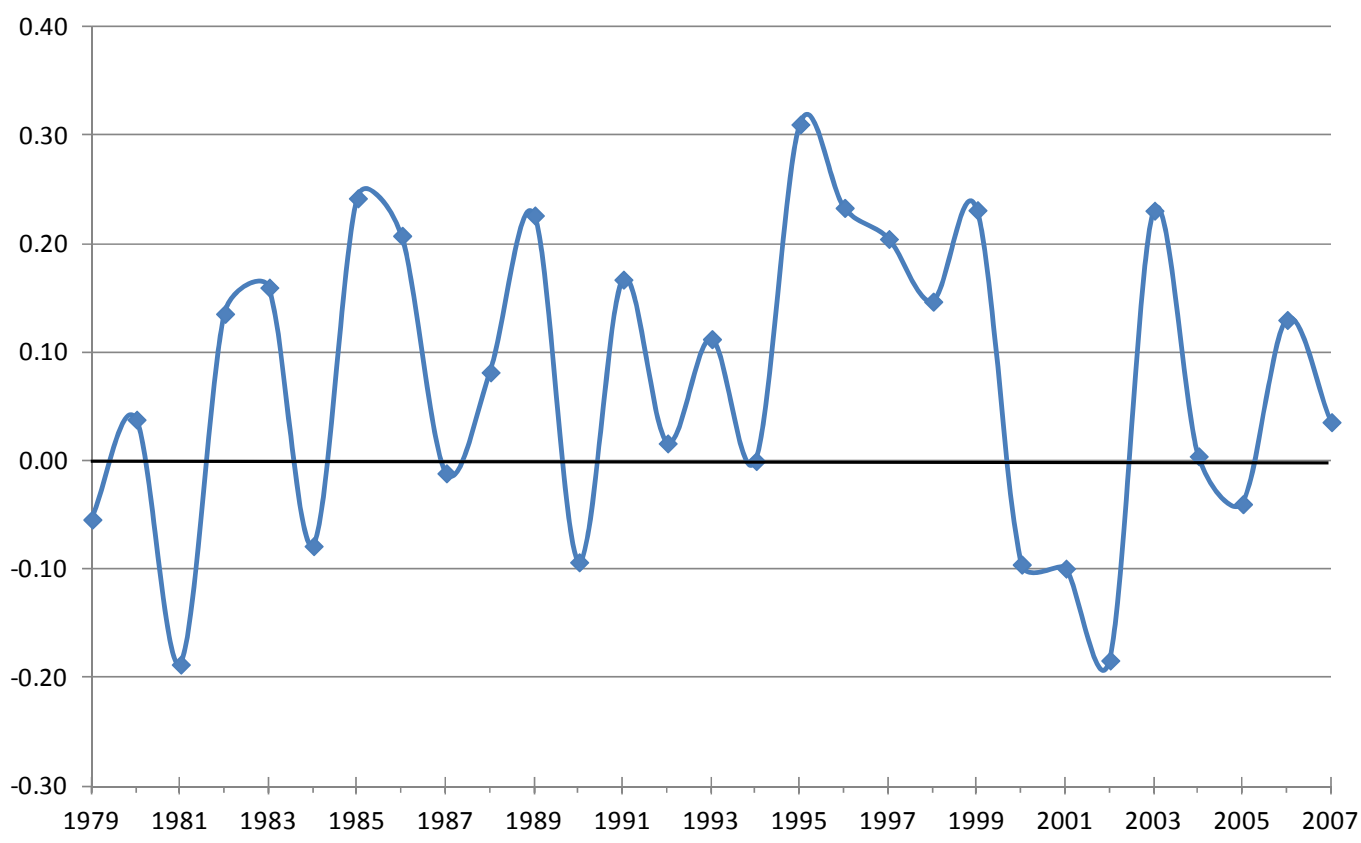

FIGURE 1. REAL INFLATION-ADJUSTED RETURN ON STOCK INVESTMENTS, BASED ON THE DOW JONES INDUSTRIAL AVERAGE, 1979-2007 


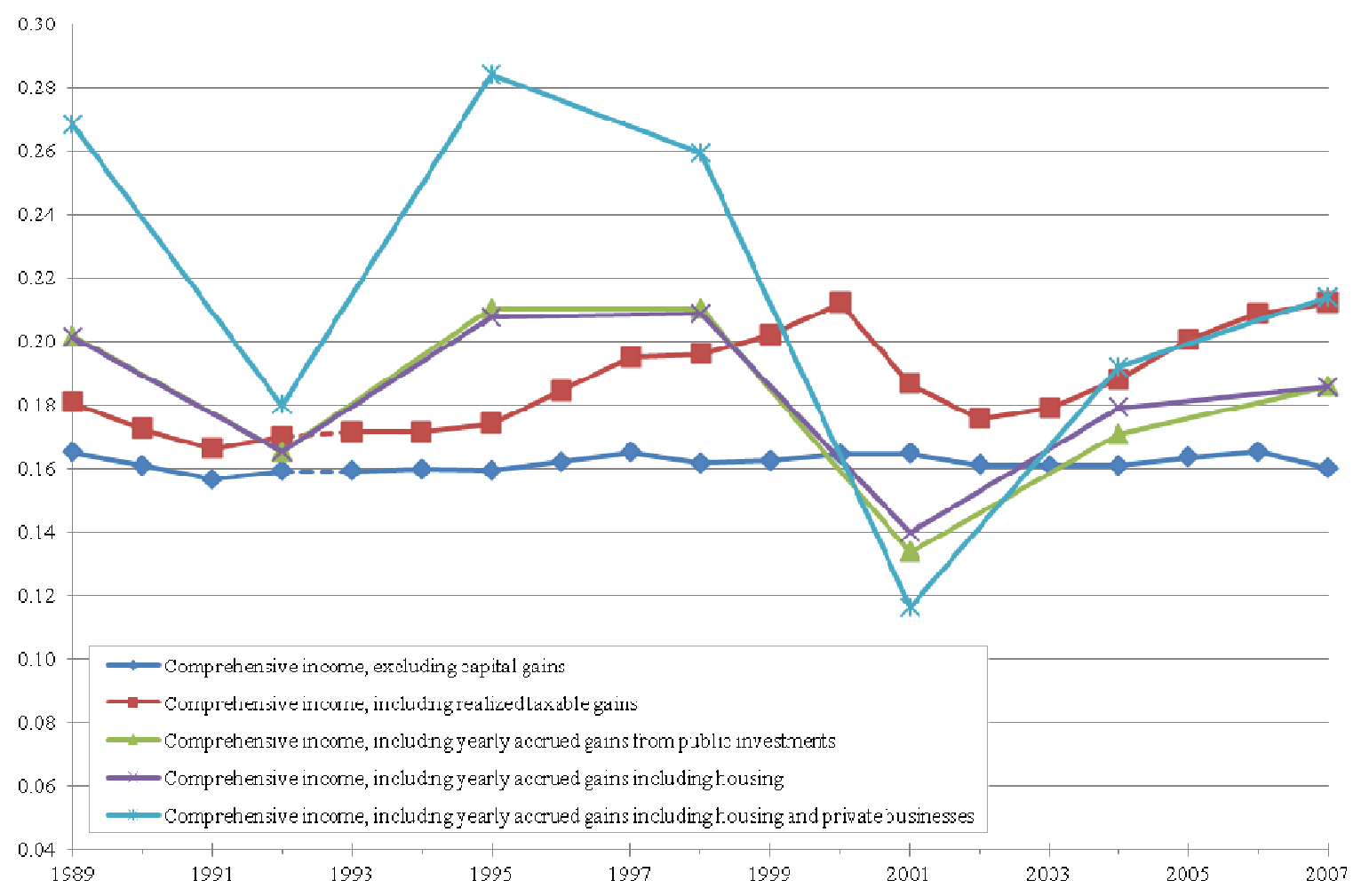

FIGURE 2. TOP 5 PERCENT INCOME SHARE USING VARIOUS COMPREHENSIVE INCOME DEFINITIONS, 1989-2007

Source: Author calculations based on March CPS data merged with SOI tax return data, Survey of Consumer Finance Data, and NBER TaxSim results.

Notes: (1) Survey of Consumer Finance Data is only available on a triennial basis, so results are displayed only for the years where that data is available. (2) Due to revisions to Census data collection procedures between 1992 and 1993, a direct comparison across these years is not possible. Following the procedure of Burkhauser et al. (2012), we assume no change in the Census-based income distribution across these two years. This adjustment is made for all four series. 


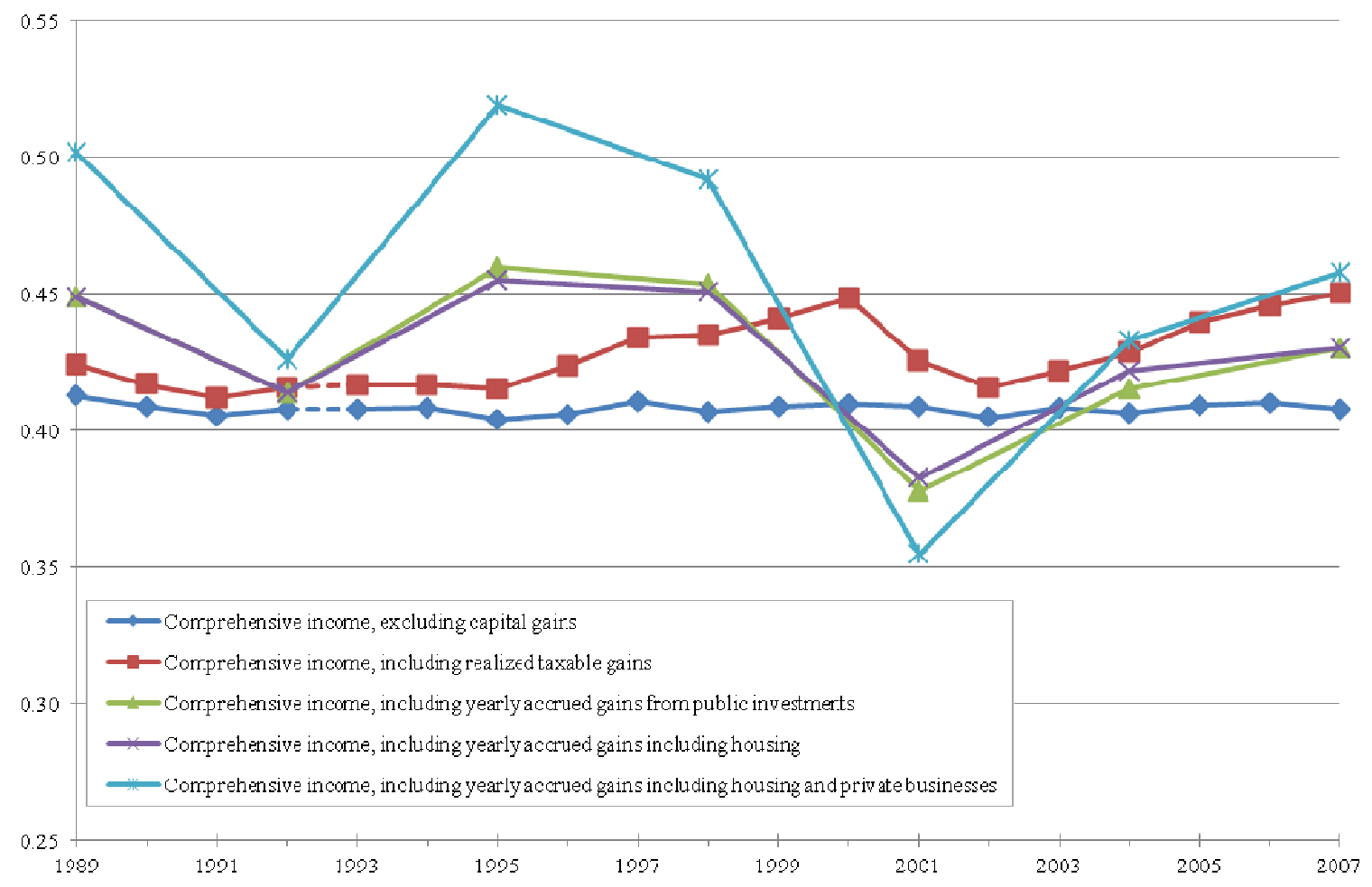

FIGURE 3. TOP QUINTILE INCOME SHARE USING VARIOUS COMPREHENSIVE INCOME DEFINITIONS, 1989-2007

Source and Notes: See Figure 2 
APPENDIX TABLE 1-ROBUSTNESS OF RESULTS FOR MEAN INCOME GROWTH BY QUINTILE BASED ON CHOICE OF ASSET APPRECIATION MEASURE FOR EQUITY ASSETS, 1989-2007

\begin{tabular}{|c|c|c|c|c|c|}
\hline & \multirow[b]{2}{*}{ (1) } & \multicolumn{2}{|c|}{$\begin{array}{c}\text { Original Results } \\
\text { Estimate accrued capital gains using the } \\
\text { annual Dow Jones Industrial Average } \\
\text { appreciation rate }\end{array}$} & \multicolumn{2}{|c|}{$\begin{array}{l}\text { Alternate Method } \\
\text { Estimate accrued capital gains using the } \\
\text { annual S\&P } 500 \text { Index appreciation rate }\end{array}$} \\
\hline & & $(2)$ & (3) & (4) & $(5)$ \\
\hline & $\begin{array}{l}\text { Household size- } \\
\text { adjusted post-tax, } \\
\text { post-transfer } \\
\text { income plus in-kind } \\
\text { income }\end{array}$ & $\begin{array}{l}\text { Column (1) plus } \\
\text { accrued capital } \\
\text { gains from public } \\
\text { investments }\end{array}$ & $\begin{array}{l}\text { Column (1) plus } \\
\text { accrued capital } \\
\text { gains, including } \\
\text { housing and } \\
\text { privately held } \\
\text { businesses }\end{array}$ & $\begin{array}{l}\text { Column (1) plus } \\
\text { accrued capital } \\
\text { gains from public } \\
\text { investments }\end{array}$ & $\begin{array}{c}\text { Column (1) plus } \\
\text { accrued capital } \\
\text { gains, including } \\
\text { housing and } \\
\text { privately held } \\
\text { businesses }\end{array}$ \\
\hline Bottom Quintile & 26.4 & 29.4 & 15.2 & 27.3 & 11.3 \\
\hline $2^{\text {nd }}$ Quintile & 22.7 & 22.9 & 3.1 & 21.0 & -0.4 \\
\hline Middle Quintile & 20.2 & 18.1 & -0.5 & 15.9 & -4.5 \\
\hline $4^{\text {th }}$ Quintile & 20.0 & 17.0 & -0.6 & 14.5 & -5.2 \\
\hline Top Quintile & 19.0 & 10.9 & -14.5 & 4.9 & -24.0 \\
\hline Top 5\% & 16.8 & 6.7 & -25.3 & -2.0 & -36.5 \\
\hline
\end{tabular}

Source: Author calculations based on March CPS data merged with SOI tax return data, Survey of Consumer Finance Data, and NBER TaxSim results 


\begin{tabular}{|c|c|c|c|}
\hline & \multirow{2}{*}{$\begin{array}{l}\text { (1) } \\
\text { Household size- } \\
\text { adjusted post-tax, post- } \\
\text { transfer income plus in- } \\
\text { kind income and } \\
\text { accrued capital gains } \\
\text { from public investments }\end{array}$} & $\begin{array}{l}\text { Original Results } \\
\text { Estimate accrued capital gains } \\
\text { for real estate using the annual } \\
\text { Federal Housing Finance Agency } \\
\text { House Price Index growth rate }\end{array}$ & $\begin{array}{l}\text { Alternate Method } \\
\text { Estimate accrued capital gains } \\
\text { for real estate using the annual } \\
\text { Case-Shiller Home Price Index } \\
\text { growth rate }\end{array}$ \\
\hline & & $\begin{array}{c}\text { (2) } \\
\text { Column (1) plus accrued capital } \\
\text { gains from housing } \\
\end{array}$ & $\begin{array}{c}\text { (3) } \\
\text { Column (1) plus accrued capital } \\
\text { gains from housing }\end{array}$ \\
\hline ttom Quintile & 29.4 & 12.9 & -20.1 \\
\hline${ }^{\text {nd }}$ Quintile & 22.9 & 8.5 & -9.4 \\
\hline Iiddle Quintile & 18.1 & 6.1 & -9.0 \\
\hline Q Quintile & 17.0 & 5.5 & -9.2 \\
\hline op Quintile & 10.9 & -0.7 & -15.6 \\
\hline op 5\% & 6.7 & -4.5 & -19.7 \\
\hline
\end{tabular}

Source: Author calculations based on March CPS data merged with SOI tax return data, Survey of Consumer Finance Data, and NBER TaxSim results 